$\mathrm{C}_{3} \mathrm{H}_{3} \mathrm{O}_{3} \mathrm{~F}: \quad \mathrm{C}, 34 \cdot 0 ; \mathrm{H}, 2 \cdot 8$ per cent; found $\mathrm{C}, 34 \cdot 0 ; \mathrm{H}, 3 \cdot 1$ per cent). It gives readily a dinitrophenylhydrazone, melting point $127^{\circ}$, and a semicarbazone (from $n$-butanol) of melting point $205^{\circ}$ (dec.) (calc. for $\mathrm{C}_{4} \mathrm{H}_{6} \mathrm{O}_{3} \mathrm{~N}_{3} \mathrm{~F}$ : C, 29.6; H, 3.7; $\mathrm{N}, 25.7$ per cent; found: C, $30.0 ; \mathrm{H}, 3.8 ; \mathrm{N}$, $25 \cdot 3$ per cent). Both derivatives showed the expected infra-red spectra; the $\mathrm{C}-\mathrm{F}$ absorption band lies at $980 \mathrm{~cm}^{-1}$.

When fluoropyruvic acid was treated with a solution of ceric sulphate in sulphuric acid in the Warburg apparatus, nearly the theoretical amount of carbon dioxide was liberated. The acid was also attacked, though slowly, by yeast carboxylase, with liberation of carbon dioxide.

The $L D 50$ for both mice and rats was $c .80 \mathrm{mgm}$./ $\mathrm{kgm}$., that is, about ten to twenty times less than the corresponding $L D 50$ for sodium fluoroacetate. No convulsive symptoms, which are so characteristic of fluoroacetate poisoning, were observed, and only a slight increase of the citric acid content in the organs of the poisoned animals was found.

In contrast to this relatively low toxicity for animals, fluoropyruvic acid shows a rather strong inhibitory effect on the growth of Escherichia coli and Aerobacter aerogenes in a synthetic medium containing ammonium salts as the sole source of nitrogen. A quantity of $20 \mu \mathrm{gm} . / \mathrm{ml}$. completely suppressed growth of the two bacteria for 24-36 hr.

Additional proof of the structure of fluoropyruvic acid was obtained in the following way. The substance was subjected to oxidative decarboxylation with hydrogen peroxide ${ }^{8}$ and the solution obtained tested for toxicity. It showed, indeed, the toxicity (to mice) which would be expected for the corresponding quantity of fluoroacetic acid, and high levels of citric acid could be demonstrated in the organs of the poisoned mice.

The study of the mode of action of fluoropyruvic acid is being continued.

J. MAGER

I. BLANK

Israeli Institute for Biological Research, Ness-Ziona.

Oct. 7.

${ }^{1}$ Martius, C., Liebigs Ann., 561, 227 (1949).

2 Liebecq, C., and Peters, R. A., Biochim. Biophys. Acta, 3, 215 (1949).

${ }^{3}$ Peters, R. A., Proc. Roy. Soc., B, 139, 143 (1952).

4 Buffa, P., and Peters, R. A., J. Physiol., 110, 488 (1949). Buffa, P.,

Peters, R. A., and Wakelin, R. W., Biochem. J, 48, 467 (1951). 140, 497 (1952).

$\checkmark$ Peters, R. A., Brit. Med. J., 1165 (1952).

- Chenoweth, M. B., J. Pharm. Exp. Therap., II, 97, 35 (1948).

- Blank, I., and Mager, J., Experientia (in the press).

${ }^{8}$ Hollemar, M. A. F., Rec. Trav. Chim. Pays-Bas, 23, 169 (1908).

\section{Separation of Volatile Acids by Paper Chromatography}

A METHOD for the identification of volatile fatty acids by means of paper chromatography was reported by Hiscox and Berridge ${ }^{\mathrm{I}}$. In this method the acid was applied as the ethylamine salt to the paper, and the chromatogram was run with water as the stationary phase and butanol as the mobile phase in an atmosphere containing ethylamine vapour. In this system the fatty acids exist as anions. On spraying the developed chromatogram with a solution of bromcresol green in ethanol, a blue spot develops where the acid anion resides on the paper.
Difficulty in the location of the acid has been experienced on a number of occasions using low concentrations of acid, due to the colour often developed in the background. If the paper is sprayed on removal from the chromatography tank without adequate volatilization of the excess base, the deep blue of the background renders all observation useless, and, on ageing, the whole field may present a mottled green appearance. If the paper is blown dry for too long a period, it is sometimes impossible to assess the acid position.

The following technique has been found useful in locating the position of the acid spots. After running, the paper is suspended in a fast stream of air drawn in by lowering the front of a fume cupboard to within a few inches of the base, and a mist spray of $\frac{1}{2}$ per cent solution of bromcresol green in ethanol is applied at short intervals, just behind the receding solvent front. The background still shows a faint blue, but wherever the acid anion resides an ovoid deep blue 'blush' appears, and this is immediately pencil-marked. Further changes in the background colours are then of no consequence, as a permanent record is obtained.

This technique, applied to the original method, has given satisfactory results over quite wide ranges of ethylamine vapour concentrations.

H. S. Burton

Sir William Dunn School of Pathology, University of Oxford. Sept. 28.

${ }^{1}$ Hiscox, E. R., and Berridge, N. J., Nature, 166, 522 (1950).

\section{Occurrence of Indole-3-Acetic Acid in Laminæ of Hevea brasiliensis}

IT became necessary during the examination of the effect of various mineral nutrients on rubber production in Hevea to investigate the occurrence of indole-3-acetic acid in the laminæ. Although it is assumed that this auxin is present in most plants, this assumption has never been verified for Hevea. Chapman ${ }^{1}$ showed by means of the Avena curvature test that in some instances the yield of rubber was related to the concentration of 'hormones' in the latex serum but did not indicate specifically that indole-3-acetic acid was present.

Numerous attempts were made in this laboratory to estimate the auxin content of laminæ using the extraction and colorimetric-estimation methods described by Henderson and Bonner2. Despite the careful fractionation of the acid and neutral fractions of the ether extracts prepared from such large quantities as $500 \mathrm{gm}$. of young laminæ, the methods were unsuccessful even after such diverse treatments as freezing, autoclaving, acid and alkaline hydrolysis or enzymatic digestion. It appeared that the quantity of auxin present was either too small for successful estimation, or that interfering substances were present which prevented the development of the pink colour. Comparatively small proportions of indole-3-acetic acid were recovered after the addition of known amounts to the leaf plus ether breis; this destruction or possible 'masking' of the auxin was not prevented by the addition of compounds known to inhibit the inactivation of auxin by various oxidizing agents and enzymes. However, using the chromatographic bioassay method devised by Luckwill ${ }^{4}$ and Bennet- 